\title{
Women's Job Search Propensity and Selection Effect in European Labour Markets
}

\author{
Rosalia Castellano, Gennaro Punzo and Antonella Rocca ${ }^{1}$
}

\begin{abstract}
The aim of this paper is to explore the main determinants of women's job search propensity and the mechanism underlying the selection effect into labour markets. The analysis compares the European countries, sharing the lowest female activity rates, with the well-developed economies of North Europe, traditionally characterized by the highest levels of female labour force participation. The potential selection bias due to the overlap in some unobserved characteristics is addressed via a bivariate probit model. Significant selection effects in women's job search process of opposite signs are found for Greece, on the one side, and for the Polish and the Norwegian labour markets, on the other one.
\end{abstract}

\section{Introduction}

Gender equality is certainly a key factor in contributing to the social progress and economic growth of a country and its influential role is most directly illustrated in the female labour force participation. The increase in women's educational attainment, the changing in their social attitudes and preferences, the improved labour market opportunities due to the tertiarization of the economy, the desire of keeping higher standards of living and the need of economic independence in response to the rise of couple relationship instability (Blau et al., 2010; Castellano et al., 2012) are only a few of "push" factors of women's job search propensity. Indeed, specific economic traits of labour market functioning are of great importance as well (McConnell et al., 2010); for example, a high local unemployment and lower household incomes could produce the need to increase the economic resources for their members' sustenance, while a high degree of labour market rigidity could make difficult for women to reconcile their work with child and home care.

\footnotetext{
${ }^{1}$ University of Naples "Parthenope", Department of Management and Quantitative Studies, via Generale Parisi 13, Naples, Italy. Corresponding Author: Gennaro Punzo, e-mail: gennaro.punzo@uniparthenope.it
} 
The importance of social policies on women economic participation and opportunities, educational attainment, health, political empowerment, work-life balance, which aim at promoting the gender equality and revitalising the labour market performance through the female participation, was perceived by European and some national institutions since 1980s. Nowadays these topics appear to be a priority on their agenda and many efforts are being made to narrow the gap between women and men. Indeed, even though with cross-country variations, the EU-27 average of female employment rates reached $58.2 \%$ in 2007 , close to the Lisbon target (60\% in 2010), increasing by 13.23 percentage points over the decade 1997-2007 (Eurostat on-line database) ${ }^{2}$. Also, the average gender gap in employment rates fell to $14.3 \%$ in 2007 from $18.6 \%$ in 1997 and the increasing participation of women in the labour market accounts for a quarter of annual economic growth since 1995 (European Commission, 2010).

However, the progress is slow and, although the women's participation in the paid labour force has been increasing throughout Europe, the female employment rate is still consistently lower than the male counterpart everywhere. As they say, men and women exhibit different patterns of labour supply (Keith and McWilliams, 1999) and different job-seeking behaviour (Kahn and Low, 1984); in general, women still appear to be less likely than men to be employed or to be looking actively for a job and gender gaps also concern pay, working hours and positions of responsibility.

These different dynamics in labour market participation between the genders which inevitably reflect social, cultural and economic norms and incentives - and the potential differences in behaviours between employed and inactive women require to deal with some important methodological issues. In this light, the aim of the paper is twofold. First, it points to explore the mechanisms underlying the selection effect in women's job search process across some European countries at different stages of economic development and with different legislation frameworks in terms of social and employment policies. The analysis involves, on the one side, four countries with the lowest rates of female labour force participation - two countries of Southern Europe (Greece and Italy) and two Eastern transition countries (Hungary and Poland) - and, on the other side, six well-developed economies of Northern Europe (Denmark, Finland, Iceland, the Netherlands, Norway and Sweden), traditionally characterized by the highest levels of female participation in the labour market. Second, after a close examination of national socio-economic background and labour market frameworks, the paper aims at exploring the main determinants of women's job search propensity and interpreting cross-country differentials in the behavior of women who are actively looking for a job in the light of the main peculiarities in the potential sample selection effect into occupation.

\footnotetext{
${ }^{2}$ http://epp.eurostat.ec.europa.eu/portal/page/portal/statistics/search_database
} 


\section{Socio-economic background of European countries}

In Europe, despite the generalized increasing share of women in paid work occurred in recent times, which shrunk the gender gap in labour market participation, cross-country differences are still quite large. Indeed, in 2007, the female activity rates ranged from the lowest values of Southern - i.e., Italy (50.7) and Greece (54.9) - and Eastern European countries - i.e., Hungary (55.1) and Poland (56.5) - to the highest incidence for the well-developed economies of North Europe - i.e., Iceland (82.7), Sweden (76.8) and Denmark (76.4) - against a EU-27 average of 63.2 per cent (Eurostat on-line database, see note 2). In general, over the five-year period (2002-2007), the female employment increased at a rate of $4.46 \%$ that was consistently higher than for men (1.18\%). As a result, the employment rate gap between the genders narrowed, but significant differences still exist across the EU; in 2007, this gap varied from less than 5\% for Finland and Sweden to more than $25 \%$ for Greece; women were more likely to have a disadvantaged position almost everywhere because their labour participation was still largely typified by a high share of precarious contracts, involuntary part-time and a persistent gender pay gap estimated at $17.6 \%$ on average. Unfortunately, indeed, the interest towards women's participation in the labour market is not even now a priority for each national government and collective bargaining.

These cross-country differences in the patterns of female labour force and their changes over time arise from a complex interaction among institutional, cultural and socio-economic dynamics (Jaumotte, 2003). In particular, the regulations of national labour markets in terms of hiring and firing structure, their degree of flexibility, the more or less restrictive policies for balancing work and family life which involve different activities related to paid work and unpaid caring as well as to social life, personal development and civic participation - may also strongly affect the women's work choices and propensities. Similarly, a more neutral tax treatment of second earners in comparison with single individuals, childcare subsidies and paid parental leaves, rather than child benefits, and tax incentives to share market work between spouses can contribute to increase female participation. Besides these, other determinants, such as female education, cultural attitudes and labour market conditions are factors that, even if only indirectly manageable, are determinants in female participation.

Countries with the lowest female participation rates strongly differ each other in terms of labour market flexibility, economic development, women's participation in higher education programs and other social and employment policies for connecting work and family life. In particular, in Italy and Greece, where the decline of marriages and the increase of births outside marriage undermined the male breadwinner model, the transition from care force to workforce has still weak social supports for childcare. Indeed, although a number of interesting family-friendly schemes were introduced, measures to support 
women in balancing work and family responsibilities and in combining work flexibility with a series of rights and guarantees are not really effective. In Greece, the labour flexibility is now at low levels if compared to the EU-average and the need for new working time arrangement is often perceived, while in Italy a greater attention has been paying to reconciliation issues. Nevertheless, attempts to increase flexibility (i.e., part-time, atypical works, job-sharing, innovative working time arrangements, telework, supplementary services) have not still reached the desired effects in terms of female labour force participation and quality of their work. Perhaps, the high levels of income inequalities and public debts distract Governments of these countries from adequate gender equality policies which are officially in force but not very actively pursued.

Just like Greece, also Poland and Hungary show the highest levels of poverty and unemployment and the lowest rates of female part-time (table 1). Anyway, it is worth stressing the existence of ambiguity in the association between part-time employment and gender equality which occurs despite a generally positive relationship between female part-time and the volume of female work. In other words, if the female part-time employment may promote flexibility because it easies the work-life balance, its impact on gender equality depends, as discussed by ILO Reports (2011), not only on the extent to which part-time substitutes for full-time employment, but also on the starting position of countries in terms of gender inequality and on the relationship between male and female employment volumes.

Table 1: General economic framework of the European countries analyzed. Year 2007.

\begin{tabular}{|c|c|c|c|c|c|c|}
\hline \multirow[b]{2}{*}{ Country } & \multirow{2}{*}{$\begin{array}{l}\text { Female } \\
\text { activity } \\
\text { rate }\end{array}$} & \multicolumn{2}{|c|}{ Unemployment rate } & \multirow{2}{*}{$\begin{array}{l}\text { Female } \\
\text { part-time } \\
\text { rate }\end{array}$} & \multirow{2}{*}{$\begin{array}{l}\text { At- risk-of } \\
\text { poverty } \\
\text { rate }\end{array}$} & \multirow{2}{*}{$\begin{array}{c}\text { Per- } \\
\text { capita } \\
\text { GDP }\end{array}$} \\
\hline & & (total) & (female) & & & \\
\hline Denmark & 76.4 & 3.8 & 4.2 & 34.7 & 16.8 & 30.6 \\
\hline Finland & 73.8 & 6.9 & 7.2 & 20.2 & 17.4 & 29.4 \\
\hline Greece & 54.9 & 8.3 & 12.8 & 9.5 & 28.3 & 22.5 \\
\hline Hungary & 55.1 & 7.4 & 7.7 & 5.5 & 29.4 & 15.4 \\
\hline Iceland & 82.7 & 2.3 & 2.3 & 36.6 & 13.0 & 30.2 \\
\hline Italy & 50.7 & 6.1 & 7.9 & 27.4 & 26.0 & 26.0 \\
\hline Netherlands & 72.2 & 3.6 & 4.1 & 75.2 & 15.7 & 33.1 \\
\hline Norway & 75.9 & 2.5 & 2.5 & 43.3 & 16.5 & 45.3 \\
\hline Poland & 56.5 & 9.6 & 10.3 & 11.9 & 34.3 & 13.6 \\
\hline Sweden & 76.8 & 6.1 & 6.5 & 39.8 & 13.9 & 31.2 \\
\hline EU-27 & 62.3 & 7.2 & 7.9 & 30.7 & 24.4 & 25.0 \\
\hline
\end{tabular}

Source: Eurostat on-line database. Year 2007

In Poland and Hungary, the female participation in the labour market and gender pay gaps - which appeared on the surface like the Nordic countries during the socialist-type regime, whose policies strongly encouraged women to work - 
worsened for the period of transition and the social policies designed to gender equality were not the main target for their Governments. However, since 2005, Hungarian and Polish Governments, in cooperation with some non-governmental organizations, have been promoting the idea of the "family-friendly" workplace and some rules on equal treatment and gender discrimination are now adopted.

Significant differences arise even across the Northern countries, where the labour flexibility and good conciliation policies represent already a reality and where the balance of work and family life remains at the top of the agenda in government policies and in collective bargaining at sectorial, national and company level. For example, in Finland, part-time is not widespread even though employees can use working time banks to satisfy flexibility needs; in the Netherlands, more opportunities are given to individuals to put together a package of conditions of employment best suited to their personal needs. Indeed, the Netherlands and Norway highlight, besides the highest per-capita GDP, the highest rates of females working part-time. Norwegian and Icelandic labour markets also show the lowest unemployment levels, but Norwegian women frequently suffer low incomes earned when the number of children increases (EFILWC, 2006). Finally, in Sweden, the high level of competition between companies stimulated the provision of additional payments for parents who want to stay at home to look after their children.

\subsection{Going beyond the North-South territorial divide}

In Europe, the manifold dynamics, which have been characterizing in these last decades the increasing patterns of female labour force participation, make too simplistic the contrast between the Southern and Eastern countries, on the one side, and the well-developed Northern economies, on the other one. Undoubtedly, more serious difficulties to find a job, especially for women, persist in the Southern and Eastern European countries; however, despite the lowest unemployment rates and successful mix of conciliation policies in the Northern Europe, substantial cross-country differences may arise for women who are in search of a job. In this field, in order to investigate more in-depth the heterogeneous socio-economic scenarios in Europe, a hierarchical cluster analysis was performed at Nuts 1 level, using the average groups linkage and the squared Euclidean distance (Fisher, 1968; Hertigan, 1975) on the basis of the following Eurostat indicators (year 2007) disaggregated at a sub-national level:

1) Female labour force participation: share of the female population aged 15 and older that is economically active.

2) Female unemployment rate: proportion of the female labour force that is without work but available for and seeking employment. 
3) At-risk-of-poverty rate: incidence of people with an equivalized disposable income after social transfers below a given threshold, which is set at $60 \%$ of the national median equivalized disposable income after social transfers.

4) Per-capita GDP: ratio between the total output of a country in terms of gross domestic product and the number of people in that country, measuring the relative performance of a country.

The cluster analysis allowed to identify six different groups of macro regions at Nuts 1 level and territorial units belonging to a same country are often classified in different groups (figure 1).

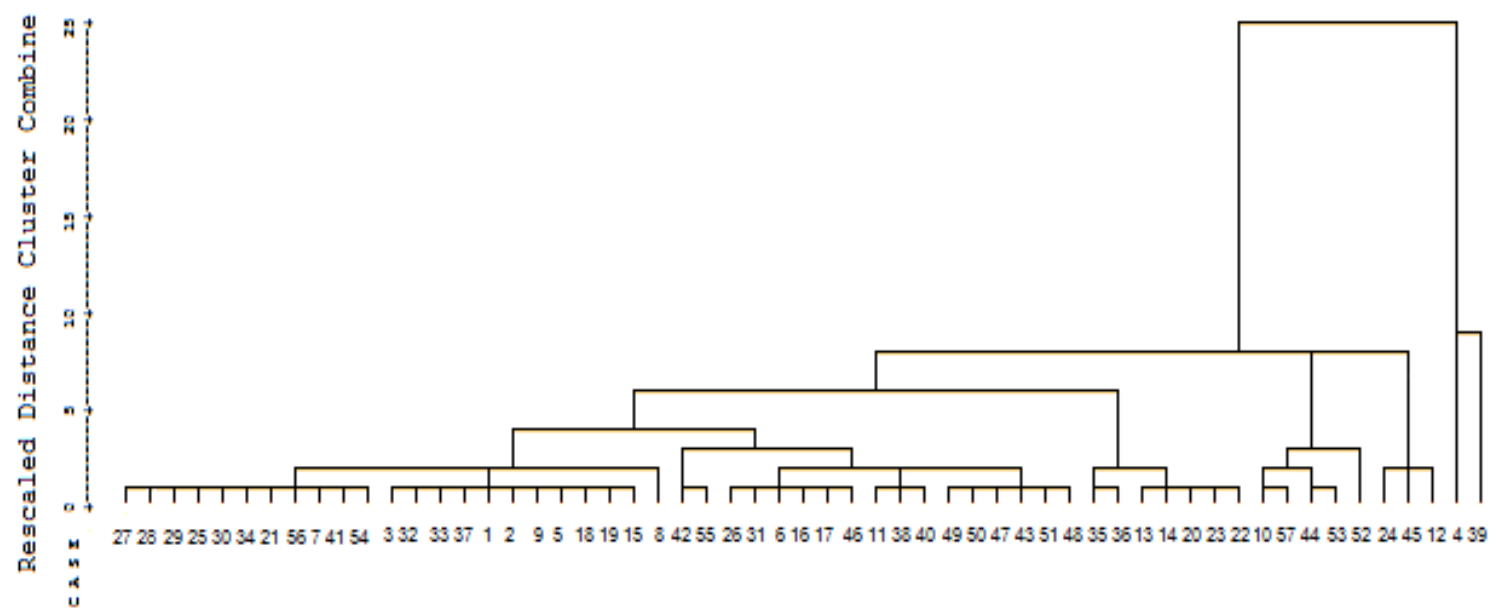

Figure 1: Dendrogram of cluster analysis at Nuts1 level. Year 2007.

\begin{tabular}{|c|c|c|c|c|c|}
\hline \multicolumn{6}{|l|}{ Legend: } \\
\hline 27: FR4 & 54: SI & 19: ES3 & 46: PL1 & 35: ITF & 53: SE \\
\hline 28: FR5 & 3: AT3 & 15: GR3 & 11: EE & 36: ITG & 52: $\mathrm{PT}$ \\
\hline 29: FR6 & 32: ITC & 8: CZ & 38: LT & 13: GR1 & 24: FR1 \\
\hline 25: FR2 & 33: ITD & 42: HU2 & 40: LV & 14: GR2 & 45: NO0 \\
\hline 30: FR7 & 37: IS & 55: SK & 49: PL4 & 20: ES4 & 12: IE \\
\hline 34: ITE & 1: AT1 & 26: FR3 & 50: PL5 & 23: ES7 & 4: BE1 \\
\hline 21: ES5 & 2: AT2 & 31: FR8 & 47: PL2 & 22: ES6 & 39: LU \\
\hline 56: FI & 9: DK & 6: BE3 & 43: HU3 & 10: DE & \\
\hline 7: CY & 5: BE2 & 16: GR4 & 51: PL6 & 57: UK & \\
\hline 41: HU1 & 18: ES2 & 17: ES1 & 48: PL3 & 44: NL & \\
\hline
\end{tabular}

Briefly, the Netherlands and Sweden, grouped with Germany and the United Kingdom, highlight the most favourable economic background, just surpassed by Norway, while Denmark, Iceland and Finland are clustered with part of South Europe, Austria, France and some Eastern countries.

Greece and the South of Italy share the highest female unemployment rates and, together with Poland, the lowest levels of per-capita GDP. Indeed, the Nuts1 detail also highlights some socio-economic dissimilarities between different territorial areas within a same country. For example, the Northern Italy as well as the North-West of Spain and the metropolitan area of Madrid appear to be more similar to the most part of France; instead, the metropolitan area of Paris runs for being one of the best performers as well Norway. 


\section{A preliminary analysis of selection effect}

The analysis draws upon the 2007 EU-SILC data (Survey on Income and Living Conditions), currently the main European reference source for comparable and multidimensional socio-economic statistics both at household and individual level; more specifically, the analysis is focused on all adult women aged 16-65.

Regardless of differences in female activity rates across countries, the different role and needs characterizing female and male workers reflect on the attitude that historically they demonstrated towards work. For example, Parsons (1991) and Keith and Williams (2002) highlight how women are less likely to search on the job than men, although they do not investigate the reasons for the se differentials. However, in the analysis of labour market dynamics, the usually-substantial extent of female non-participation might cause problems of sample selection because working women could be unrepresentative of the entire female population. In other words, women who do not work may differ in some important unmeasured ways (i.e., individual status, family-specific or socio-cultural background) from women who choose to belong to the active population; this may even lead to biased estimates of structural relevant parameters for working women behaviour (Killingsworth and Heckman, 1986; Maddala, 1983).

Indeed, in estimating the Mincerian wage equations by gender, many Authors (Albrecht et al., 2009; Mulligan and Rubinstein, 2008; Wooldridge, 2002) stressed the need to take into account the potential sample selection for females because working women may form a self-selected sub-sample which makes the estimations biased. In general, in order to inspect the relationship between earnings and schooling/post-school investments, in the original Mincer models (1958; 1974), the logarithm of earnings is modelled on a set of human capital variables (i.e., education and labour market experience). In other words, the formal education at different levels (i.e., early childhood, school-based compulsory education, postcompulsory and tertiary education, etc.), the non-formal enterprise-based training (or public labour market training) and the experience acquired in working life are considered as the most relevant life-wide settings to human capital formation.

However, the heterogeneous and dynamic nature of human capital, regarded as accumulation and interaction of more intangible assets with the capacity to support or enhance productivity and employability, has been recognized over time. Therefore, following some extensions of the basic Mincer earnings functions (Willis and Rosen, 1979; Behrman and Birdsall, 1983; Card and Krueger, 1992), in a previous work (Quintano et al., 2013), a range of other characteristics at individual (marital status, health status) and household level (presence of dependent children) as well as a host of factors that could affect earnings (professional qualification, activity sector, type of contract, number of weekly working hours, firm size, degree of supervisor, urbanization degree of residence area) are also modelled. 
Preliminarily, in order to manage the selection effect, the two-stage Heckman procedure (Heckman, 1979) was tested. In the first stage, a reduced form of probit equation, including some women's characteristics both at personal (age, marital status, education) and household level (dependent children, the ratio of familiar earners, urbanisation degree of residence area) was assessed on the whole sample of working and inactive women in order to estimate their propensity to work and to compute the selectivity term $(\lambda)$ :

$$
z_{i f}^{*}=Y_{i}^{F} \gamma+u_{i}^{F} \quad \Rightarrow \quad z_{i f}=I\left(z_{i 1}^{*}>0\right) \quad \text { with } \quad u_{i}^{F} \sim N\left(0, \sigma_{u}^{2}\right), \quad i=1, \ldots, n
$$

where $\mathrm{I}\left({ }^{\cdot}\right)$ is an indicator function giving 1 if the condition holds and 0 otherwise and the selection variable (propensity to work) is not observed because it is just known if the woman is occupied or not. Therefore:

$$
\begin{aligned}
& P\left(z_{\text {if }}=1\right)=\phi\left(Y_{i}^{F} \gamma\right) \\
& P\left(z_{\text {if }}=0\right)=1-\phi\left(Y_{i}^{F} \gamma\right)
\end{aligned}
$$

In the second stage, the Mincerian earnings equation for female workers is corrected for the occupational selection:

$$
E\left(Y_{i}^{F} \mid X_{i}^{F}, z_{i f}=1\right)=X_{i}^{F} \beta^{F}+E\left(\varepsilon_{i}^{F} \mid u_{i}^{F}>-Y_{i}^{F} \gamma\right)=X_{i}^{F} \beta^{F}+\lambda_{i}^{F} \theta^{F}
$$

where the correction term for selectivity:

$$
\lambda_{i}^{F}=\frac{\phi\left(Y_{i}^{F} \gamma\right)}{\Phi\left(Y_{i}^{F} \gamma\right)}
$$

is the inverse of Mill's ratio, $\phi($.$) and \Phi($.$) are the probability density and the$ cumulative standard normal distribution functions.

For significant values of $\lambda$ coefficient $(\theta)$, sample bias is confirmed and corrected and consistent estimations of the earnings equation for females is obtained. The lambda coefficient $(\theta)$ is an estimation of the parameter identified as the product of the standard deviation of the errors in the wage equation and the correlation between the errors from the wage equation and the errors from the selection equation (Neuman and Oaxaca, 2004).

Empirical results of women's wage equations (table 2), estimated over 26 European countries through the Heckman procedure, showed lambda coefficients significant and negatively signed for each country (except for Norway). This suggests a negative correlation between the error terms of the selection probit and the primary wage models. It means that unobserved factors, which make female labour force participation more likely, tend to be associated with lower potential returns. 
Women's job search propensity and selection effect in European labour markets 91

Table 2 - Lambda coefficients over 26 European countries on the Mincerian wage equations. Year 2007.

\begin{tabular}{l|l|l|c}
\hline \multicolumn{1}{c|}{ Country } & $\lambda$ Coefficient & \multicolumn{1}{|c}{ Country } & $\lambda$ Coefficient \\
\hline Austria & $-0.29807^{* * *}$ & Italy & $-0.16126^{* * *}$ \\
Belgium & $-0.54024^{* * *}$ & Latvia & $-0.96101^{* * *}$ \\
Cyprus & $-0.39348^{* * *}$ & Lithuania & $-0.78201^{* * *}$ \\
Czech Republic & $-0.66854^{* * *}$ & Luxembourg & $-0.30978^{* * *}$ \\
Denmark & $-2.08190^{* * *}$ & the Netherlands & $-0.61911^{* * *}$ \\
Estonia & $-1.20022^{* * *}$ & Norway & 0.09560 \\
Finland & $-1.05783^{* * *}$ & Poland & $-0.59788^{* * *}$ \\
France & $-0.73739^{* * *}$ & Portugal & $-0.31405^{* * *}$ \\
Germany & $-0.22876^{* * *}$ & Slovakia & $-1.62603^{* * *}$ \\
Greece & $-0.25662^{* * *}$ & Slovenia & $-0.53048^{* * *}$ \\
Hungary & $-0.57680^{* * *}$ & Spain & $-0.30628^{* * *}$ \\
Iceland & $-0.76499^{* * *}$ & Sweden & $-1.35408^{* * *}$ \\
Ireland & $-0.65874^{* * *}$ & the United Kingdom & $-0.08448^{* *}$ \\
\hline *Sigific
\end{tabular}

"Significant at $10 \%,{ }^{* *}$ Significant at $5 \%,{ }^{* * *}$ Significant at $1 \%$

\section{Methodology: a bivariate probit model}

The evidence from the two-stage Heckman procedure (tab. 2) stimulated the interest to explore the main determinants of women's job search propensity as well as the mechanism underlying the selection effect across the European countries with opposite levels of female participation in the labour market. Since the job search is conditional upon participation and employment, the current levels of female labour force participation may strongly affect who is actively looking for a job; thus, the potential overlap in unobserved characteristics influencing both the women's propensity to work and to look actively for a job is addressed via a bivariate probit model (Green, 1997). In other words, the analysis of job search propensity through a univariate probit model could be potentially biased because the decision to engage in job search is just observed when a woman is not employed.

With the aim to evaluate the influence of personal (age, marital status, educational attainment) and family characteristics (dependent children, urbanization, ratio) on the probability that a woman who does not work is actively searching for a job, a first probit model estimates the probability that a woman is not occupied:

$$
y_{i 1}^{*}=X_{i}^{F} \gamma+\varepsilon_{i 1}^{F} \quad \Rightarrow \quad y_{i 1}=I\left(y_{i 1}^{*}>0\right)
$$

where $\mathrm{I}($.$) , as in the (3.1), is an indicator function giving 1$ if the condition holds and 0 otherwise. 
Focusing on the subset of women who do not work, the probability of being actively searching a job is given by:

$$
y_{i 2}^{*}=X_{i}^{F} \gamma+W_{i}^{F} \delta+\varepsilon_{i 2} \quad \Rightarrow \quad y_{i 2}=I\left(y_{i 2}^{*}>0\right)
$$

including a set of additional covariates (W) concerning the equivalized household income and size, the individual health status and the geographical area of residence; $\gamma$ and $\delta$ are the unknown parameters. The joint error structure of models is defined in the following way:

$$
\left(\begin{array}{l}
\varepsilon_{i 1} \\
\varepsilon_{i 2}
\end{array}\right) \sim \operatorname{Normal}\left(\left(\begin{array}{l}
0 \\
0
\end{array}\right),\left(\begin{array}{ll}
1 & \rho \\
\rho & 1
\end{array}\right)\right)
$$

that is the error vectors are assumed to be independent but their components are correlated.

In this way, the potential for unobserved heterogeneity that could produce a correlation between the error terms of the two probit models is considered. Therefore, not only the true effects of looking for a job, but also the effect on professional condition of having these unobservable characteristics are captured (Fleming and Kler, 2011). If the error terms $\varepsilon_{\mathrm{i} 1}$ and $\varepsilon_{\mathrm{i} 2}$, jointly distributed as bivariate normal with zero means and constant variances, are significantly positive correlated $(\rho>0)$, unobserved factors increase both the probability of being an unemployed female and looking for a job; for significantly negative $\rho$, the reverse is true, while not significant $\rho$ shows the absence of selection effect and the equivalence of using the bivariate or two separate probit models.

\section{Main results}

By justifying the bivariate probit model in the effort to limit the risk of selection bias, it allows to estimate the probability of the event to be actively searching for a job upon the condition to be unemployed.

Significant selection effects of opposite signs are found for Greece, on the one side, and Norway and Poland, on the other one (table 3). The selection effect in women's job search process is insignificant for all the other countries and this could derive from a lack of a link between the mechanisms of job search and the status of unemployed. Probably, in the Northern countries, where the female labour force participation is the highest one and the female unemployment is low, the actively searching for a job is mainly linked to a form of frictional unemployment, just resulting from a labour market turnover. Conversely, in the other countries, where the female unemployment is higher, the attendant persistence of the male breadwinner model, especially in some specific social 
classes, could act in opposite directions, inducing women with a poorer background to look for low qualified jobs, while women with higher human capital could reveal a less attitude to search a job. Therefore, the significance of lambda coefficients for the Heckman correction in the women's wage equations (table 2) could denote a sample selection which exclusively involves women that do not participate at all to labour force.

In Greece, the harsher scenario and the more difficulties to find a job drive both the propensity of being unemployed and negatively the propensity of actively seeking employment; probably, this is due to the lack of real opportunities which could discourage Greek women in job searching, regardless their high propensity to work. In Norway and Poland, the unmeasured factors associated to a lower propensity to search a job act in the opposite direction. Indeed, for these two countries, so as for Denmark and the Netherlands, the women's job search propensity is not significantly linked to financial household problems; as they say, a lower total family income does not necessarily imply more pressure on the unemployed women to be more active in job search. However, for Polish, Icelandic and Scandinavian women, to be married does not decrease the propensity to be actively looking for a job in contrast to Southern countries. Briefly, for the Northern countries, one of the most important findings is that neither marriage nor the presence of dependent children never discourage women to be active in the labour market; in Denmark, living in a larger household with more dependent children even seems to put more pressure to search a job.

As the classical human capital theory suggests (Becker, 1964; Mincer, 1958; Schultz, 1961) and consistent with other empirical studies (Smirnova, 2003; Smith, 2003; Eriksson et al., 2002), our results emphasize the crucial role of education and age in determining both the propensity to work and the propensity to search a job. Indeed, a higher educational attainment significantly increases the job search propensity everywhere, except for Iceland and the Netherlands; job search is expected to pay more educated females off more than the less educated ones, while younger women are usually more active in search. Certainly, this latter is a negative effect which leads older women to decrease their search effort because of discouragement.

Norway - the only country for which no selection effect exists in the labour market but exclusively in the job search process - shows the best performance on the whole. Moreover, in the selection equation, the negative relationship between the ratio variable (i.e., number of earners on total household components) and the probability of not working denotes a higher female propensity to work in families where more members are already occupied. Nevertheless, beyond Italian, Greek and Hungarian women, even for the Finnish and Swedish ones, working still appears to be linked to financial household problems. As they say, even in countries with more favourable labour market conditions, in terms of functioning and conciliation policies, some social and economic problems are still unsurpassed. 
Table 3: Bivariate probit estimates of non-working and actively searching for a job.

Year 2007 (to be continued)

\begin{tabular}{|c|c|c|c|c|c|}
\hline Variables & Italy & Greece & Hungary & Poland & Denmark \\
\hline $\begin{array}{l}\text { Actively searching for a job } \\
\text { Intercept } \\
\text { Equivalised household } \\
\text { income } \\
\text { Marital status (1 if married) } \\
\text { Education attain. (ref: low) } \\
\text { Medium (ISCED97: } 3 ; 4) \\
\text { High (ISCED97: 5) } \\
\text { Children (1 if with children) } \\
\text { Age class (ref.: } 16-24 \text { years) } \\
\text { Younger [25-40 years] } \\
\text { Older [41-65 years] } \\
\text { Health (1 if chronic) } \\
\text { Ratio(+) } \\
\text { Equivalised household size } \\
\text { Urbanisation (1 if densely) } \\
\text { Geographical area } \\
\text { (Nuts1)(++) } \\
\text { Area } 1 \\
\text { Area } 2 \\
\text { Area } 3 \\
\text { Area } 4 \\
\text { Area } 5\end{array}$ & $\begin{array}{l}0.3672^{* * *} \\
-0.4022^{* * *} \\
-0.0598 \\
0.2999 \\
0.1588^{* * *} \\
-0.0576\end{array}$ & $\begin{array}{l}0.4762^{* * *} \\
-0.0109 \\
-0.0731^{\text {*** }} \\
1.8186^{* * *} \\
0.2206^{\text {*** }} \\
-0.0773\end{array}$ & $\begin{array}{c}0.2798^{* * *} \\
0.6385^{* * *} \\
-0.2834^{* *} \\
-0.3924^{*} \\
0.9193^{* * *} \\
0.7179^{* * *} \\
1.0821^{\text {** }} \\
0.1319^{* *} \\
0.0446\end{array}$ & $\begin{array}{c}0.5373^{\text {*** }} \\
-0.2661^{\text {*** }} \\
-0.4220^{\text {*** }} \\
0.4272^{\text {*** }} \\
-0.2661^{\text {*** }} \\
-0.3056^{\text {*** }} \\
0.4861^{*} \\
0.0952^{\text {** }} \\
0.0786\end{array}$ & $\begin{array}{r}0.2456 \\
0.2211 \\
-0.1257 \\
0.2326 \\
-0.2529 \\
-0.0975\end{array}$ \\
\hline $\begin{array}{l}\text { Not working } \\
\text { Intercept } \\
\text { Age (years) } \\
\text { Marital status ( } 1 \text { if married) } \\
\text { Children ( } 1 \text { if with children) } \\
\text { Urbanisation (1 densely) }\end{array}$ & $\begin{array}{c}3.5105^{\text {*** }} \\
-0.0092^{* * *} \\
0.0962^{\text {** }} \\
0.5082^{\text {*** }} \\
0.1256^{\text {*** }}\end{array}$ & $\begin{array}{l}3.5638^{* * *} \\
-0.0115^{* * *} \\
0.0677^{* *} \\
0.4875^{* * *} \\
0.1002^{* *}\end{array}$ & $\begin{array}{l}3.8445^{* * *} \\
-0.0140^{* * *} \\
-0.2143^{* * *} \\
0.4473^{* * *} \\
0.0352\end{array}$ & $\begin{array}{l}3.2892^{* * *} \\
-0.0016^{* * *} \\
-0.3350^{* * *} \\
0.2833^{* * *} \\
0.0871^{\text {*** }}\end{array}$ & $\begin{array}{l}3.1707^{* * *} \\
-0.0079^{* * *} \\
-0.1118^{*} \\
0.3422^{* * *} \\
-0.1007\end{array}$ \\
\hline $\begin{array}{l}\text { Education attain. (ref: low) } \\
\text { Medium (ISCED97: 3;4) } \\
\text { High (ISCED97: 5) } \\
\text { Ratio (+) }\end{array}$ & $\begin{array}{l}-0.4432^{* * *} \\
-0.9438^{* * *} \\
-4.4691^{* * *}\end{array}$ & $\begin{array}{l}-0.4274^{* * *} \\
-0.9553^{* * *} \\
-4.3516^{* * *}\end{array}$ & $\begin{array}{l}-0.5901^{* * *} \\
-0.9686^{* * *} \\
-4.3045^{* * *}\end{array}$ & $\begin{array}{l}-0.8561^{* * * *} \\
-1.4804^{* * *} \\
-3.5013^{* * *}\end{array}$ & $\begin{array}{l}-0.6393^{* * *} \\
-0.7967^{* * *} \\
-3.9472^{* * *}\end{array}$ \\
\hline $\mathrm{N}$ & 12,642 & 7,707 & 17,217 & 4,515 & 4,856 \\
\hline $\begin{array}{l}\text { Wald chi2 } \\
\text { Correlation }(\rho)\end{array}$ & $\begin{array}{c}429.33 \\
-0.2390\end{array}$ & $\begin{array}{c}\frac{317.55}{0.6858^{* *}} \\
0.6\end{array}$ & $\begin{array}{l}188.26 \\
0.1859\end{array}$ & $\begin{array}{c}313.94 \\
-0.3482^{* *}\end{array}$ & $\begin{array}{c}47.03 \\
-0.0441\end{array}$ \\
\hline
\end{tabular}

Significant at $10 \%,{ }^{* *}$ Significant at $5 \%,{ }^{* * *}$ Significant at $1 \%$

$(+)\left(\mathrm{n}^{\circ}\right.$ earners -1$) /\left(\mathrm{n}^{\circ}\right.$ household members $)$;

(++) Nuts1 codes: Italy: 1 North-West, 2 North-East, 3 Centre, 4 South (ref.: Isles); Greece: 1 Voreia, 2

Kentriki, 3 Attiki (ref.: Nisia Aigaiou, Kriti); Hungary: 1 Central, 2 Transdanubia (ref.: Greath Plain and North); Poland: 1 Centralny, 2 Poludniowy, 3 Wschodni, 4 Polnocno-Zachodni, 5 Poludniowo-Zachodni (ref.: Polnocny) 
Table 3 (continued): Bivariate probit estimates of non-working and actively searching for a job. Year 2007.

\begin{tabular}{|c|c|c|c|c|c|}
\hline Variables & Finland & Iceland & $\begin{array}{c}\text { The } \\
\text { Netherlands }\end{array}$ & Norway & Sweden \\
\hline $\begin{array}{l}\text { Actively searching for a job } \\
\text { Intercept }\end{array}$ & $-0.8346^{* * *}$ & -0.5184 & $-2.0794^{* * *}$ & $-1.8449^{* * *}$ & $-1.2503^{* *}$ \\
\hline $\begin{array}{l}\text { Equivalised household } \\
\text { income }\end{array}$ & $-0.00003^{* * *}$ & $-0.000004^{*}$ & -0.000004 & -0.000001 & $-0.00002^{* *}$ \\
\hline Marital status ( 1 if married) & -0.0652 & 0.1311 & $-0.4441^{* * *}$ & -0.1532 & -0.1046 \\
\hline Education att & & & & & \\
\hline Medium (ISCED97: $3 ; 4$ ) & $0.5071^{* * *}$ & 0.0141 & 0.0136 & $0.4657^{* * *}$ & $0.6558^{* * * *}$ \\
\hline High (ISCED97: 5) & $0.5283^{* * *}$ & 0.4270 & 0.4057 & $0.8198^{* * *}$ & $0.6286^{* *}$ \\
\hline Children ( 1 if with children) & -0.0299 & -0.0951 & 0.1181 & -0.0225 & -0.1686 \\
\hline Age class (ref.: & & & & & \\
\hline Youn & $0.3064^{* *}$ & $-0.3924^{*}$ & $0.6690^{* * *}$ & 0.1206 & 0.1711 \\
\hline Older $[41-($ & 0.140 & -0.92 & $0.3518 *$ & $0.3206^{* *}$ & -0.0741 \\
\hline Health ( 1 if chronic) & $-0.4590^{* * *}$ & 0.1630 & 0.1801 & -0.0373 & $-0.3252^{* *}$ \\
\hline Ratio (+) & 0.0346 & -0.1690 & 1.1182 & $2.7657^{* * *}$ & $1.7085^{*}$ \\
\hline Equiv & -0.15 & -0.1811 & -0.0823 & -0.1912 & $-0.1771^{*}$ \\
\hline Urbanisation (1 if $d e r$ & & & - & -0.0156 & \\
\hline Not working & & & & & \\
\hline Intercept & $4.6366^{* * *}$ & $3.9635^{* * *}$ & $2.1514^{* * * *}$ & $3.1005^{* * *}$ & $5.3980^{* * *}$ \\
\hline Age (years) & -0.02 & $-0.0346^{* * *}$ & 0.00002 & $-0.1292^{* * *}$ & $-0.0206^{* * *}$ \\
\hline Marital status ( 1 if married) & -0.03 & 0.0 & 0.0523 & 0.0103 & -0.0978 \\
\hline Children ( 1 if with children) & $0.6646^{* * *}$ & 0.0706 & $0.4295^{* * *}$ & $0.1562^{* * *}$ & $0.2613^{* * *}$ \\
\hline Urbanisation (1 densely) & $-0.1723^{* * *}$ & 0.0028 & - & -0.0338 & 0.0480 \\
\hline inment (ref. low) & & & & & \\
\hline Medium (ISCED97: $3 ; 4$ ) & $-0.7345^{* * *}$ & $-0.3815^{* * *}$ & $-0.6040^{* * *}$ & $-0.6282^{* * *}$ & $-1.1402^{* * *}$ \\
\hline High (ISCED97: 5) & $-0.8696^{* * *}$ & $-0.8463^{* * *}$ & $-0.9731^{* * * *}$ & $0.9539^{* * *}$ & $-1.3522^{* * *}$ \\
\hline Ratio (+) & $-5.3240^{* * * *}$ & $-3.6586^{* * *}$ & $-3.2250^{* * *}$ & $-3.5753^{* * * *}$ & $-5.6301^{* * *}$ \\
\hline $\mathrm{N}$ & 8,913 & 2,788 & 8,392 & 4,749 & 5,796 \\
\hline Wald chi2 & 87.44 & 24.27 & 45.04 & 179.70 & 81.67 \\
\hline Correlation $(\rho)$ & 0.0585 & 0.1136 & -0.1972 & $-0.9343^{*}$ & -0.4644 \\
\hline
\end{tabular}

Significant at $10 \%,{ }^{* *}$ Significant at $5 \%,{ }^{* * *}$ Significant at $1 \%$

$(+)\left(n^{\circ}\right.$ earners -1$) /\left(n^{\circ}\right.$ household members $)$

\section{Concluding remarks}

The growth of female labour force participation is a feasible channel for increasing per capita GDP and, in turn, for narrowing the gender gaps. This is of great importance, mainly in recent years characterized by a reduced economic growth even for the most developed European countries. The emphasis of EU institutions on economic and social policies devised to support gender equality and innovative forms of work organization and legislation produced a further increase in the female labour force participation, driving national governments on the definition of various measures for reconciling work and family life.

However, substantial cross-national differences in the levels of female participation in the labour market still persist. In this light, in Europe, the wellknown contraposition between the most developed Northern economies, on the one 
side, and the Southern and Eastern countries, on the other one, whose economic growth is obstructed by many socio-economic problems, is too much simplistic and lacking of significance in explaining the se differentials.

In this paper, an in-depth analysis of determinants of women's job search activity has been carried out with a particular focus on the influence of household composition, trying to link the results to each national macroeconomic framework. Indeed, institutions surely play a crucial role in stimulating the women's participation in the labour market through initiatives increasing flexibility or different kinds of employment and labour tax policies, although the decision to be active in the labour market is also strongly affected by the choices in fertility and education.

The analysis of countries with opposite levels of female activity rates has shown a significant selection effect only for Greece, Poland and Norway. In particular, in Greece, the negative sign of selection effect could highlight a strong influence of financial problems and high levels of unemployment in female propensity of actively looking for a job; on the other side, Polish and Norwegian women seem to be driven in their decisions in finding a job by opposite factors. In the other countries, different dynamics, such as different levels of unemployment, part-time diffusion, persistence of the male breadwinner model, don't let emerge any predominant aspect.

Furthermore, in the Northern countries having children does not significantly affect the propensity to search a job, probably thanks to a successful mix of conciliation policies designed to encouraging simultaneously female participation and motherhood; by contrary, in the Southern and Eastern countries it could be still a problem because even if some programs targeted for working mothers have been implemented, the burden of childbearing is left to the family. However, many common factors across countries are also identified, such as the direct relationship between educational level and propensity to work.

Briefly, women's work propensity appears to be higher in countries where a good mix of social policies aimed primarily to reconciling motherhood with professional life are in force, although the macroeconomic scenarios and the strictness of labour market institutions may negatively affect their participation.

\section{Acknowledgements}

The authors would like to thank the referees for their useful suggestions and comments on some general and technical issues that led to many improvements in the work. 


\section{References}

[1] Albrecht, J., Van, Vuuren, A. and Vroman, S. (2009): Counterfactual Distributions with Sample Selection Adjustments: Econometric Theory and an Application to the Netherlands. Labour Economics, 16, 4, 383-396.

[2] Becker, G.S. (1964): Human Capital. Columbia University Press.

[3] Behrman, J.R., Birdsall, N. (1983): The Quality of Schooling: Quantity Alone is Misleading. American Economic Review, 73, 5, 928-946.

[4] Blau, F., Ferber, M. and Winkler, A. (2010): The Economics of Women, Men and Work. Prentice Hall.

[5] Card, D., Krueger, A.B. (1992): Does School Quality Matter? Returns to Education and the Characteristics of Public Schools in the United States. Journal of Political Economy, 100, 1-40.

[6] Castellano, R., Punzo, G. and Rocca, A. (2012): Intergenerational Mobility and Gender Gap: Evidence from Mediterranean Countries. Proceedings of 46th Scientific Meeting of the Italian Statistical Society, Rome (Italy).

[7] Eriksson, T., Lilja, R. and Torp, H. (2002): Determinants of Job Search Intensity: Some Evidence from the Nordic Countries. Labor Institute for Economic Research Discussion Papers, 185, 1-38.

[8] European Commission (2010): Report on equality between women and men, Luxembourg: Publications Office of the European Union.

[9] European Foundation for the Improvement of Living and Working Conditions - EFILWC (2006): Reconciliation of work and family life and collective bargaining in the European Union.

[10] Fisher, W.D. (1968): Clustering and Aggregation in Economics. John Hopkins, Baltimore.

[11] Fleming, C.M. and Kler, P. (2011): I'm too Clever for This Job: a Bivariate Probit Analysis on Over-Education and Job Satisfaction in Australia. Applied Economics, 40, 9, 1123-1138.

[12] Green, W.H. (1997): Econometric Analysis. Prentice Hall.

[13] Heckman, J. (1979): Sample Selection Bias as a Specification Error. Econometrica, 47, 1, 153-161.

[14] Hertigan, J.A. (1975): Clustering Algorithm. John Wiley \& Sons, New York.

[15] International Labour Organization (2011): Key indicators of the Labour Market. Seventh Edition, ILO.

[16] Jaumotte, F. (2003): Female Labour Force Participation: Past Trends and Main Determinants in OECD Countries. OECD Economics Department Working Papers, 376, OECD Publishing. 
[17] Kahn, L.M. and Low, S.A. (1984): An Empirical Model of Employed Search, Unemployed Search and Non-search. The Journal of Human Resources, XIX 1.

[18] Keith, K. and McWilliams, A. (1999): The Returns to Mobility and Job Search by Gender. Industrial and Labor Relations Review, 52, 3, 460-477.

[19] Keith, K. and Williams, D.R. (2002): A Note on Racial Differences in Employed Male Job Search. Industrial Relations, 41, 3, 422-429.

[20] Killingsworth, M. and Heckman, J.J. (1986): Female Labor Supply: A Survey, Handbook of Labor Economics. vol. I, Elsevier Science Publishers.

[21] Maddala, G. S. (1983): Limited-Dependent and Qualitative Variables in Econometrics. Cambridge: Cambridge University Press.

[22] McConnell, C.R., Brue, S.S. and Macpherson, D.A. (2010): Contemporary Labor Economics. 9th edition, McGraw Hill.

[23] Mincer, J. (1958): Investment in Human Capital and Personal Income Distribution. Journal of Political Economy, 66, 4, 281-302.

[24] Mincer, J. (1974): Schooling, Experience and Earnings. New York: National Bureau of Economic Research.

[25] Mulligan, C. and Rubinstein, Y. (2008): Selection, investment and women's relative wage over time. Quarterly Journal of Economics, 123, 3.

[26] Neuman, S. and Oaxaca, R.L. (2004): Wage decompositions with selectivitycorrected wage equations: a methodological note. Journal of Economic Inequality, 2, 3-10.

[27] Parsons, D.O. (1991): The Job Search Behavior of Employed Youth. Review of Economics and Statistics, 73, 4, 597-604.

[28] Quintano, C., Castellano, R., Rocca, A. (2013): A Cross-Country Analysis of Gender Pay Gap and Segregation. Italian Journal of Applied Statistics, vol. 2, 2, 157-183.

[29] Schultz, T.W. (1961): Investment in Human Capital. The American Economic Review, 51, 1, 1-17.

[30] Smirnova, N. (2003): Job search behavior of unemployed in Russia. Bank of Finland Discussion Papers, 13, 1-36.

[31] Smith, S. (2003): Labor Economics. Routledge.

[32] Willis, R.J. and Rosen, S. (1979): Education and Self-Selection. J. Polit. Econ., 87, 5.

[33] Wooldridge, J.M. (2002): Econometric analysis of cross section and panel data. MIT Press: Cambridge, MA. 